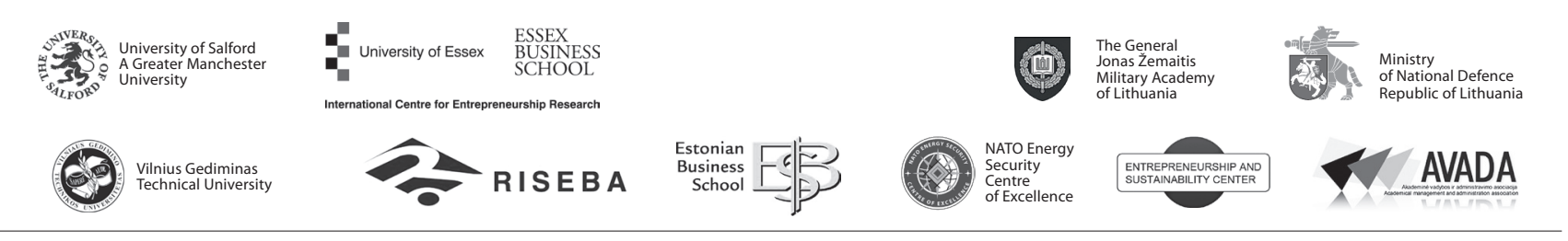

\author{
JOURNAL OF SECURITY AND SUSTAINABILITY ISSUES \\ ISSN 2029-7017 print/ISSN 2029-7025 online \\ 2018 March Volume 7 Number 3 \\ http://doi.org/10.9770/jssi.2018.7.3(19)
}

\title{
TRANSFORMATION OF ECONOMY TOWARDS TOURISM: CASE OF KAZAKHSTAN
}

\author{
Anna Shevyakova ${ }^{1}$, Irina Tyugina ${ }^{2}$, Malika Arystan $^{3}$, Eleonora Munsh $^{4}$ \\ ${ }^{1}$ LLP "RATIONAL SOLUTION", Orbit-1, 11/1, Karaganda, 100022, Kazakhstan \\ 2 The National Chamber of Entrepreneurs of Kazakhstan "Atameken", \\ Department of Small Business Development, Kunaev str. 8, Astana, 010000, Republic of Kazakhstan \\ ${ }^{3}$ Karaganda Economic University, Department of economic and management, \\ Akademicheskaya str. 9, Karaganda, 100000, Republic of Kazakhstan \\ ${ }^{4}$ EPAM Kazakhstan, Training and Development Department, Ermekova str., 58/3, \\ Karaganda, 100000 Republic of Kazakhstan
}

E-mails: ${ }^{1}$ shevyakova.anna@gmail.com; ${ }^{2}$.tyugina@palata.kz; ${ }^{3}$ malika_arystan@mail.ru; ${ }^{4}$ eleonoria@list.ru

Received 20 May 2017; accepted 14 December 2017

\begin{abstract}
In the tourist practice, the information support of tourism activities provides the comfort of tourist services and the attractiveness of the region enhances the motivation of consumers to visit this territory, which leads in the development of entrepreneurship. The development of tourism demand accelerates diversification in the economy creates new types of proposals in entrepreneurship. Non-governmental organizations in Kazakhstan, as well as all over the world, can play an active role in the promotion of regions, the individual settlements and the events. The latest advances of telecommunications, network organizations, the creation and processing of databases and e-marketing provide new business opportunities in the tourism sector. Therefore, the main sphere of changes and innovations in the sphere of tourism is connected with using of information and communication technologies. Kazakhstan with its unique natural resources and original culture of the nomadic people has a huge untapped potential for tourism development in the international and regional markets. Tourism as a type of business in the Republic of Kazakhstan is recognized as one of the priority branches of the economy at the state level. Modern trends in the development of the industry is consisted in the fact that tourists who have studied well the most famous resorts of the world are eager for those countries where the tourism sector is just beginning to develop. At the present stage of tourism development, Kazakhstan is becoming a more attractive country for lovers of extreme species and / or ethnographic tourism. The tourist potential of recreational resources, historical and cultural heritage may allow Kazakhstan to harmoniously integrate into the international tourist market. It can ensure stable employment and income growth, stimulate the development of related industries and lead to an increase in investment flows in the national economy.
\end{abstract}

Keywords: Kazakhstan; economic sectors; pre-employment; tourism; non-governmental organizations; information technologies and support; computer networks; diversification

Reference to this paper should be made as follows: Shevyakova, A.; Tyugina, I.; Arystan, M.; Munsh, E. 2018. Transformation of economy towards tourism: case of Kazakhstan, Journal of Security and Sustainability Issues 7(3): 601-616.

http://doi.org/10.9770/jssi.2018.7.3(19)

JEL Classification: L31, O53 


\section{Introduction}

The fundamental changes are happened in the world economy, aggravated with the geopolitical crisis and the sanctions policies of the leading powers introduce the amendments in economic policy of Kazakhstan. The Republic of Kazakhstan is obliged by today's progress in social and economic development and attraction of the foreign investments to such basic factors of competitiveness as security with natural resources, the favorable macroeconomic environment and political stability. But the economy of Republic of Kazakhstan already partially loses competitiveness and is in "a trap of average income" (Tvaronavičienè, Gatautis 2017). For the preservation of high rates of economic growth the Republic of Kazakhstan will need to realize the structural changes in economy necessary for transition to a new stage of development. In this regard the problem of the diversification of the economy remains relevant for Kazakhstan.

One of the main features of development of economy of Kazakhstan still remains a dominant position of oil and gas and raw sectors due to weakening of the position of the Kazakhstan manufacturing industry and also replacement from structure of consumption of domestic goods by import goods. At the same time in raw character of the Kazakhstan economy, its weak diversification it is possible to see the main reason of the repeating economic crises.

The issues of economic development have been taken into account regional peculiarities, peculiarities of formation of associations of countries and the formation of economic and political associations, have been repeatedly considered in the writings of economists and sociologists (eg Delmon, 2015: Menšsikovs \& Ignatjeva \& Stankevičs, 2014; Boronenko \& Lavrinenko, 2015; Shevyakova et al., 2016; Štiglic, 2017; Jurigová et al., 2017; Stjepanović et al., 2017).

The most significant changes in the structure of GDP have taken place in 2014-2016 therefore following the results of 2016 the share of a manufacturing sector was reduced to $36 \%$ from $45,1 \%$ in 2010 , a share of the mining industry - to 12,9 with 19,5 , and the share of the service sector has increased from $51,7 \%$ to $57,9 \%$.

It should be noted that the raw nature of structure of industrial production of Kazakhstan not only provided until recently forward development of national economy, but also is the most reliable source of her growth in the nearest future. However, as it has shown a world economic crisis, domination of raw branches in structure of national economy results in instability of economic growth and long stagnation. Therefore for Kazakhstan the strategic importance gains need of carrying out the critical analysis of institutional and market changes in economy of Kazakhstan for modernization of state policy and extent of intervention in economy for increase in its competitiveness, overcoming raw orientation and ensuring sustained economic growth of the country and certain regions.

Super profits in raw branches and corresponding demand for their production really block a free modulation of the capital in the processing sector and the service sector. Especially destructive were consequences of the accelerated dismantling of state ownership for the branches and productions referred now to real economy. The economic development of Kazakhstan can be characterized as depending on the oil and gas and mining export sector and a high real exchange rate so far. Therefore, the susceptibility of economy to world price fluctuations so-called a boom - sectors is high. A position of the companies' monopolists in raw branches, which highly profitable and extremely profitable, such is that they aren't interested in development of the processing sector, except for small projects on improvement of technological indicators within extraction of raw materials or raw repartition. Domination of raw branches is a basic obstacle for ensuring long-term economic growth, does the country dependent on an environment of the world markets.

For 2000 - 2017 the raw orientation of the Kazakhstan economy hasn't decreased, and her dependence on the external economic environment has amplified. It should be noted that the raw nature of structure of industrial production of Kazakhstan not only provided until recently forward development of national economy, but also is the most reliable source of her growth in the nearest future. However, as has shown a world economic crisis, 
domination of raw branches in structure of national economy results in instability of economic growth and long stagnation. Therefore for Kazakhstan the strategic importance gains need of carrying out purposeful state policy of diversification and modernization of economy for increase in its competitiveness, overcoming raw orientation and ensuring sustained economic growth of the country and certain regions.

The relevance of the aforesaid is confirmed by the analysis of the major quality indicators. So, in structure of GDP of Kazakhstan the essential share is the share of raw branches. First of all, on the branch fuel-energy complex and metallurgy. Such situation affects also structure of the Kazakhstan export which indicator only on the commodity operations connected with oil, gas, metals makes the lion's share. The structure of import of the Republic of Kazakhstan is presented by such groups of goods as machine and equipment, finished products from metal and other types of the industrial processed output. This situation is explained by underdevelopment of the manufacturing industry capable to release goods with high value added. So exported crude oil comes back to our country in the form of products deep processing and high value added.

Fixing of Kazakhstan in the status of the oil state bears in itself and big problems: underinvestment of the overworking sectors of economy, instability of growth rates owing to dependence on an external environment, reduction of jobs and, certainly, strengthening of social and economic stratification of the population. Increase and strengthening of negative manifestations in economy of Kazakhstan, including devaluation, the second for one and a half year, speak about an entrance to a final stage of that economic and political model which foundation has been laid in the second half of the 90th years and which has gained the development and fixing in recent years. To her base export of oil, crude uranium, ferrous and non-ferrous metals, in exchange for import is put in Kazakhstan of the equipment and the materials for the same raw export and which aren't manufactured in Kazakhstan of goods for satisfaction of consumer demand. Respectively, within such model in Kazakhstan actually raw export and also transport, trade and financial infrastructure for delivery and distribution about the country of final foreign goods developed.

The external economic and political environment develops in such a way that growth rates of world economy, and, means also consumption of production of the Kazakhstan export, will only be slowed down. Also increase in the world prices for oil and metals isn't expected - their decrease and fixing at the certain steady level is observed. And such amicably negative estimates are given by world experts on prospect of the next two-three years, at least.

If oil, ferrous and non-ferrous metals, let and not at the prices giving excess profits, all the same are in demand in the world market, it is possible to break negative tendencies due to quantitative building of production of export-oriented productions. The main thing in exhaustion of sources of development of such economic model. The rate on foreign investments, in a compartment with the budgetary investment and investment started on raw income at the expense of means of the export enterprises has led to strengthening and fixing of export and raw orientation of the Kazakhstan economy. As speculation reflection of export and raw orientation, the delivery economy to the country and trade in the industrial and consumer goods which aren't made here has developed, has developed and has gained a foothold in Kazakhstan. She has received the considerable share of investment too - in the form of transport and retail chain stores and financial infrastructure. And this part of economy which is consuming the lion's share of export revenue, most of all suffering from the shortage of foreign currency and devaluation of currency national doesn't facilitate too, and aggravates the general crisis state.

The deadlock final of the economic model built in Kazakhstan is put in her initial genesis - sovereign embedding into the world market. In such "independent" option Kazakhstan is necessary to the system of global division of labor only as the territory of the reduced the price production of energy and mineral resources on export and also - already to a lesser extent, for sale of production of industrially more developed economies here. And, certainly, for exclusively external monetary providing supplementing export not of renewable natural resources also export of the most part of financial income.

Real options for an independent breakthrough from such a well-rounded and packaged in a monocentric global model of the scheme of neo-colonial raw material and monetary exploitation from Kazakhstan, as yet, do not exist. 
In the same way attempts to reduce currency and commodity dependence on import are strongly limited. His main part (about $43 \%$ ) is made by machines, the equipment and vehicles which establishing alternative production exceeds not only financial and investment, but also general opportunities actually of Kazakhstan. Further (about $8 \%$ ) there is chemical production, including rubbers and plastic - here possibilities of replacement are limited too. And only food dependence Kazakhstan can (and has to) to liquidate almost entirely - but it is rather small (about $10 \%$ ) a share of everything imported.

However, from each deadlock there is the exit, and any crisis bears with itself not only tests, but also opportunities. As both the economic model, and sources of her development approach exhaustion, other model and others sometimes non-standard sources are necessary.

\section{Tourism development as way of diversification of economy of Kazakhstan}

From 2000 for 2016 inflow of the direct foreign investments (DFI) to national economy has made more than 1.3 billion US dollars. At the same time more than two thirds of such investments went to mining branches (32.6\% of gross inflow of PII) and activities for carrying out geological investigation and researches (37.0\%). Only $8.8 \%$ of all PII, and on an agriculture share $-0.1 \%$ fall to the share of manufacturing industry. Thus, for the considered period the raw orientation of the Kazakhstan economy hasn't decreased, and her dependence on the external economic environment has amplified.

One of important questions of the current development is diversification of streams of direct foreign investments in economy Kazakhstan which need to be sent to the perspective and dynamically developing branches, for example, the sphere of tourism. Kazakhstan, having rich tourist and recreational potential, it is characterized by the insufficient level of development of tourism. His share in gross domestic product doesn't reach even $1 \%$. According to United Nations World Tourism Organization (The report of 2016), in world export of goods and services tourism takes the 3rd place (7\%) after export of fuel and chemical products. In 2015 on export indicators tourism has outstripped food and automobile branches. In some developed countries tourism takes the 1st place in export of goods and services. According to World Travel \& Tourism Council for 2015, the tourism share in world GDP makes $10 \%$, every 11 th person in the world works in the tourist sphere, and the number of the international tourist arrivals has made 1186 million US dollars, having increased in a year by 52 million US dollars. On profitability this branch takes the third place in the world after the oil-extracting industry and automotive industry.

The Republic of Kazakhstan with its extensive territory, favorable in respect of trade relations between Europe and Asia by the geographical location rich with the cultural and historical heritage and traditions which have remained till these days has all reasons for successful development of tourism. There are five main economic and social interests to consider tourism as one of national priorities of development in the Republic of Kazakhstan:

- an opportunity to provide in the sphere of tourism over 250 thousand jobs, including the population of the rural and remote areas and youth without separation from a traditional rural way of life;

- assistance to cultural development of business activity among a general population, creating business opportunities for families, small and medium-sized enterprises;

- a contribution to development of regions and the rural areas of the Republic of Kazakhstan, including development of engineering and transport infrastructure in the remote areas, infrastructures of check points through Frontier of the Republic of Kazakhstan;

- assistance to cooperation and creation of opportunities in other sectors of economy, including agriculture, mechanical engineering, the light and food industry, the non-productive sector;

- assistance to creation of the positive and productive cross-cultural relations promoting advance of national 
and interstate mutual understanding.

Development of entrance and internal tourism in Kazakhstan will depend on a number of market tendencies - in tourism in general, economy, demography, ecology, technology, and other spheres. But in the course of carrying out the analysis it is modern conditions of tourist branch of Kazakhstan were the following problems are revealed:

- the prevalence of the small travel companies which don't have personnel and material resources doesn't contribute to the development of investment investments in branch of tourism;

- backwardness of transport infrastructure. Small quantity of both regular, and charter foreign flights. Development of tourism is limited to high transport expenses. There are no specialized motor transportation enterprises for tourist activity. Also the system of electronic booking and planning of trips isn't created;

- discrepancy of statistical account to the international standards and lack of complex objective accounting of economic effect of tourist activity;

- discrepancy to the international standards of system of modern education and training of qualified personnel for the tourist industry;

- weak level of financing of development of tourism in regions, etc.

From types of tourism in Kazakhstan outbound tourism (figure 1) prevails. The number of the visitors who have left the country exceeds the number of the visitors who have driven to the country by 1.8 times. Trips on the personal purposes have made in $201681.8 \%$ of total of trips to Kazakhstan, trips on the business and professional purposes $-17.2 \%$. At the same time private visits have made $90.0 \%$ of trips on the personal purposes (transit $9.1 \%$, tourism $-0.9 \%$ ). During the period from 2011 to 2016 sure increase in number of the leaving tourists from 8.0 million people in 2011 up to 12.1 million people in 2016 was observed. The quantity driving in the considered period fluctuated: having increased from 5.7 million people in 2011 to 6.8 million people in 2013, the indicator was reduced to 6.3 million people in 2014, and then again has increased up to 7.4 million people in 2016.

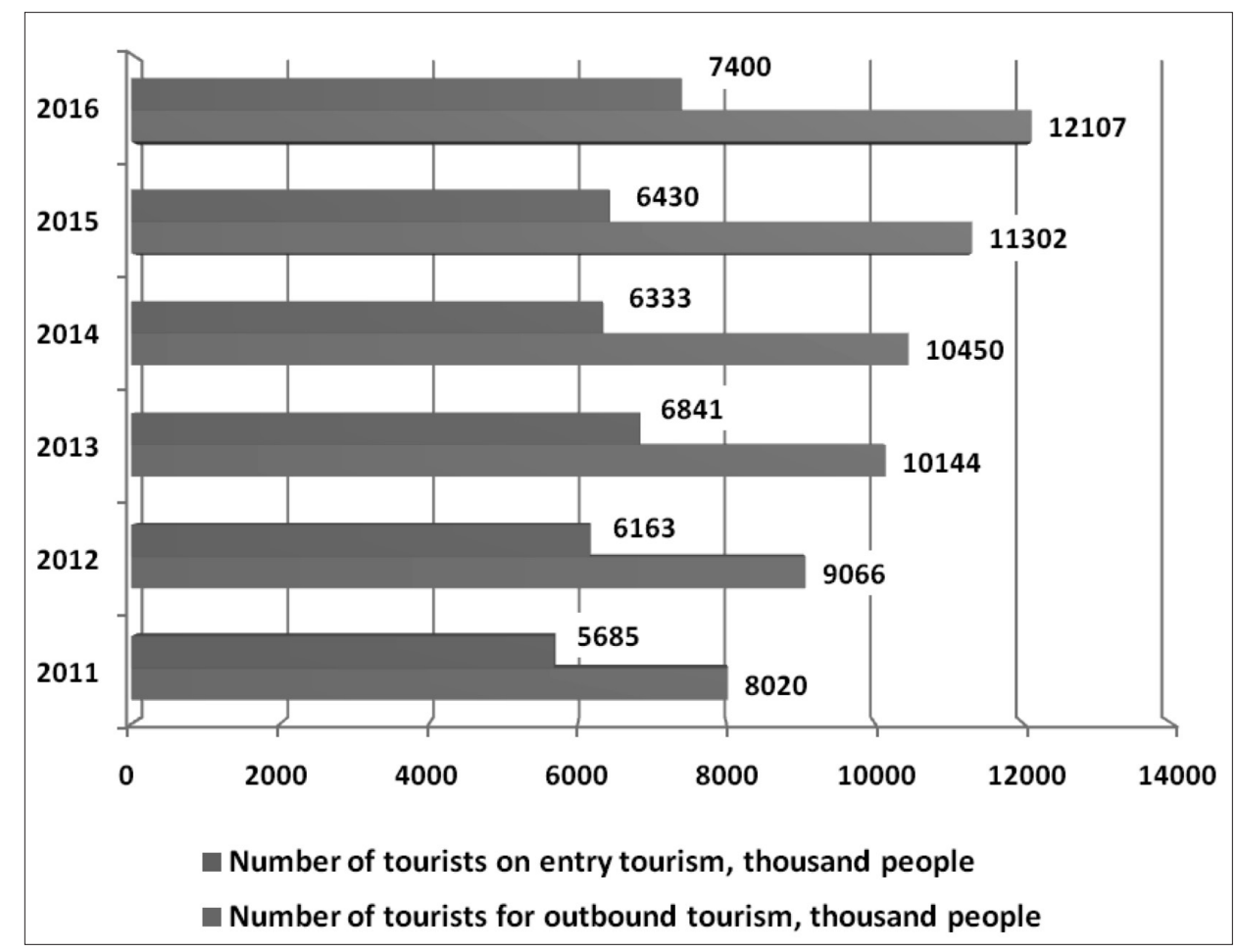

Fig. 1. Number of visitors by type of tourism in Kazakhstan 
Main problem of the Kazakhstan tourism: entrance tourism as a concept of Kazakhstan is absent. According to data of Committee on statistics of the Republic of Kazakhstan, for example, in 1 quarter 2016 in our country there have arrived 144.7 thousand foreigners. It is 13 thousand more than a last year's indicator (in $2015 \mathrm{Ka}$ zakhstan has accepted 692 thousand foreigners, hotels have rendered services for 73 billion KZT or 0.18 billion euros). That is, it seems, the popularity of Kazakhstan steadily grows - in 10 years the number of Intourists has grown three times, and the volume of revenues of branch has increased by 5 times. However if to compare these data at least to data from Uzbekistan ( 2 million tourists for 2015 - tenfold growth in 10 years), you understand that Kazakhstan takes the 85th place in the world on tourism development by right.

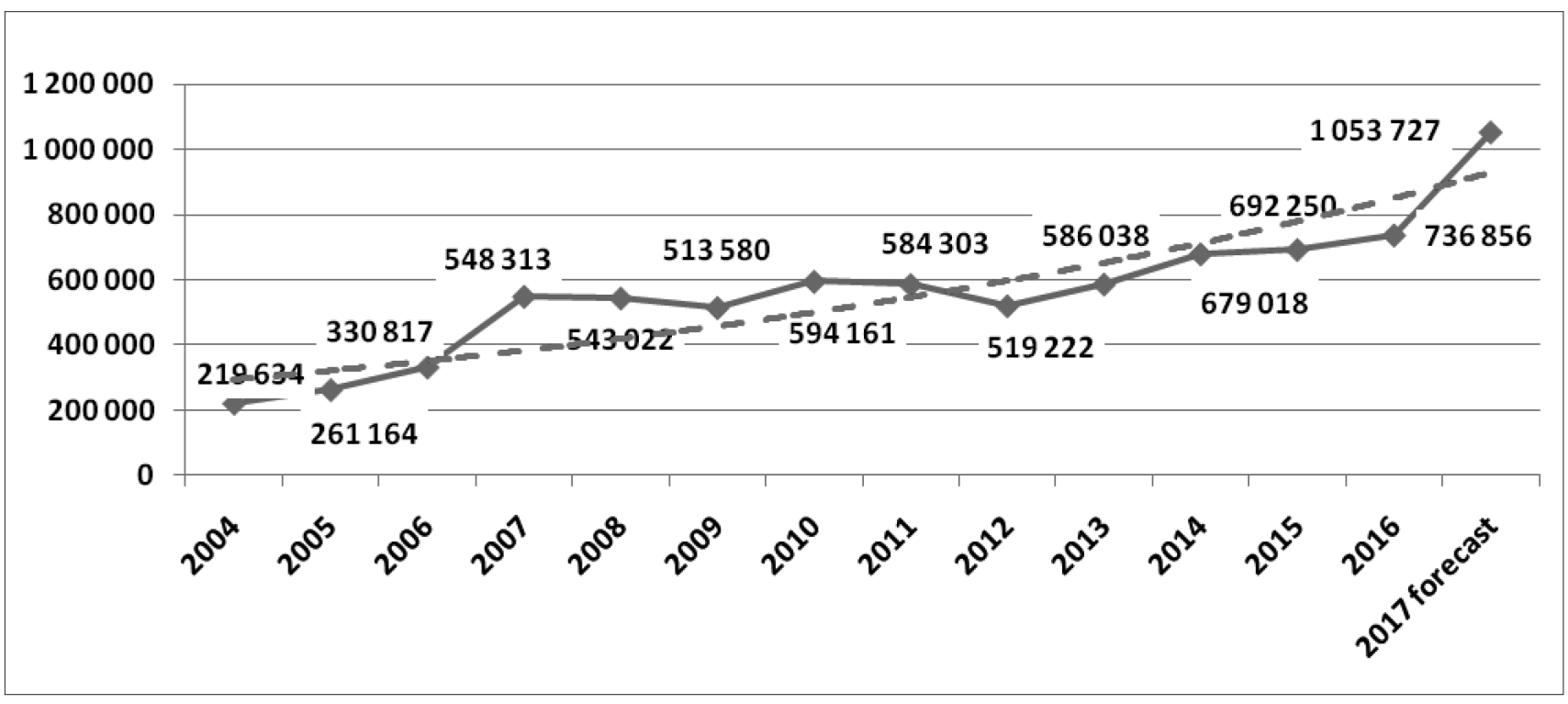

Fig. 2. Number of non-residents of the Republic of Kazakhstan served in the places of residence, people

Source: composed by the authors

The international experience shows that the active role of executive power in infrastructure ensuring development of tourism is one of considerable factors of success. Forms of the state support of development of tourism are rather diverse, however it is possible to allocate some examples which correspond to current state of Kazakhstan on a number of signs:

- an active role of the state in modernization of the country by direct participation in economy;

- lack of natural development of resort areas, as a rule, because of remoteness, lack of infrastructure and backwardness of domestic market by this type of tourism. B examples with such conditions the state actively created the new offer in tourism by the centralized development of the resort "from scratch", constructions of infrastructure and tourist objects. Commercial objects in these resorts were under construction either at the expense of public funds or with attraction of private investments. As a rule, the state created for these purposes of the national operator whose activity had quasi-commercial character.

Despite the supposedly active support from the state of tourism in Kazakhstan, many issues remain unresolved for the simple reason that the development of tourism does not depend on a separate ministry, non-governmental organization or business community. Tourism in Kazakhstan directly and indirectly depends on 32 branches and state agencies which are responsible for those spheres to which the tourist adjoins from the moment of crossing of border of Kazakhstan until departure ... from border control and migration police, to the doorkeeper of hotel and even the huntsman of national park. It is enough to tell what coordinated with all interested public authorities of the Concept of development of tourism of Kazakhstan till 2020 is under consideration of Presidential Administration since February, 2013. 
In the world have already passed to tripartite management of tourism where is,

- the first, the public coordinating body in the form of the Ministry of tourism which resolves issues of the general regulation coordination, licensing and state policy (he at us exists);

- the second, regional (city) managements of tourism which represent the interests of tourism in municipal authorities (are available in structures of management);

- the third, convent-and-visitor-bureau in the cities (CVB) which are engaged in marketing of a tourist's product and conference rooms which role with success non-governmental organizations could carry out.

Creation (CVB) could take place as non-profit organization, quasi-public structure, or in a format of PPP in the cities of Astana and Almaty with introduction of tourist collecting bedtax. This collecting is successfully applied in the USA, Europe, Latvia, etc. Dubai has introduced tourist collecting in anticipation of the EXPO of 2020. Charge of at least 1 dollar for room-night will collect in Astana more than 1 million dollars a year and this with the fact that we have already passed opportunities EXPO-2017. In addition CVB, controls quality of service and the provided services to tourists. For today at us these functions are performed by nobody.

The spontaneous Kazakhstan market of tourist services which has developed in recent years, in general, in the absence of the coordinating beginning is in crisis state, and the Kazakhstan objects, despite the huge recreational capacity of the country, still aren't included in constant international tourist chains. One of the reasons of a similar contradiction consists in lack of solid and reliable information about a condition of the market and service the, habitual for western client, who is based on all opportunities provided with modern means of communication. For today, process of formation and sending tourist groups abroad and, on the contrary, without use of information technologies is insufficiently effective even in Astana and Almaty.

Kazakhstan Tourist Association (KTA) was founded in May 1999 with the support of the President of the Republic of Kazakhstan. KTA is a non-profit (NPO) non-governmental organization (NGO). The KTA includes the Kazakhstan Association of Hotels and Restaurants (KAGiR), the representative office of the company «Amadeus GDS», tourist, insurance and airlines, universities and media. The Association stands for the protection of the interests of its members (today there are more than 100 of them), carries out lobbying and propaganda of the tourist industry of the Republic of Kazakhstan.In Committee of tourist branch of National chamber of businessmen of the Republic of Kazakhstan of Atameken 8 branch associations uniting 542 members are accredited.

Nevertheless, to date, the entire tourism industry in Kazakhstan needs an organization that would inform tourists, support the sellers of tourist services, facilitate the tourism business in the search for potential customers and promote services, support the creation of a full cycle of tourism services, coordinate the efforts of all stakeholders in providing the best quality tourism services, developed and supported destination strategies, supported the implementation of the strategy, one hundred and would be the official face and voice of the Kazakh tourism industry.

Preliminary data for 2017 look insufficiently hopefully, despite the number of the regulating and allegedly helping structures. 
Table 1. Preliminary statistical information of branch of tourism in Kazakhstan for 2017

\begin{tabular}{|c|c|c|c|c|}
\hline No. & Name of Indicator & Value & $\begin{array}{l}\text { Deviation } \\
\text { (2016) }\end{array}$ & Note \\
\hline 1 & Share of tourist branch in GDP & $1.3 \%$ & $+0.3 \%$ & The forecast for 2025 is $8 \%$. \\
\hline 2 & Number of tour agencies, including: & 4247 & & \\
\hline 2.1 & Tour Operators & 1450 & & \\
\hline 2.2 & Travel Agents & 2826 & & \\
\hline \multirow[t]{2}{*}{3} & Placements: & & & \\
\hline & $\begin{array}{l}\text { Number of placements } \\
\text { (including by category) }\end{array}$ & 2997 & +243 & $\begin{array}{c}*-22 \\
4 *-89 \\
3 *-132 \\
2 *-18 \\
1^{*}-15 \\
\text { other }-2721\end{array}$ \\
\hline 3.1 & Number of rooms & 66555 & +6128 & \\
\hline 4 & Placement Fallibility & $25.4 \%$ & $+0.9 \%$ & \\
\hline 4.1 & Volume of services provided by placements & $\begin{array}{l}0.21 \text { billion euros } \\
84.8 \text { billion KZT }\end{array}$ & $+38 \%$ & \\
\hline 4.2 & Number of visitors served & $\begin{array}{c}4108 \text { thousand } \\
\text { people }\end{array}$ & & \\
\hline \multirow[t]{2}{*}{4.2 .1} & Residents & 3428 & & \\
\hline & Non-residents & 685 & & \\
\hline 5 & Tourists & thousand people & & \\
\hline 5.1 & Number of domestic tourists & 4368 & $+25 \%$ & \\
\hline 5.2 & Number of visitors & 5838 & $+18 \%$ & \\
\hline 5.3 & Number of people leaving Kazakhstan & 7920 & $+5 \%$ & \\
\hline 6 & Balance of payments (million US dollars) & -109.3 & & (data for 2016) \\
\hline 7 & Number of employees in the tourism industry: & thousand people & & \\
\hline 7.1 & Placements & 26.5 & $+17 \%$ & \\
\hline 7.2 & Sanatorium-and-spa institutions & 10.0 & $+5 \%$ & \\
\hline 7.3 & Travel Agencies & 7.2 & $+2.3 \%$ & \\
\hline
\end{tabular}

Source: composed by the authors

Data for 2017 can be considered to some extent as irrelevant as in Astana there took place the EXPO-2017 exhibition that has led to sharp increase in indicators which however is difficult for considering positive. In the EXPO-2017, 100 states and more than 10 international organizations took part. The exhibition was visited by about 4 million people, of whom only 0.5 million came from other countries, that is, the fallibility of the exhibition was provided by domestic tourism. Unfortunately only $15 \%$ of guests were made by foreign tourists of 187 countries of the world that allows speaking about the insufficient level of information support both the action, and all types and opportunities of tourism in Kazakhstan.

The cities of Astana and Almaty are the most important tourist centers where the greatest number of the locations conforming to the international standards is concentrated. Generally the locations offered outside the specified cities do not conform to the international quality standards, and are focused generally on the Kazakhstan tourists. In the large cities there is a deficiency of hotels of category $3 *$ and $4 *$. The absolute majority of foreign orders and bookings of hotel rooms happens on the Internet. About 15\% of the Kazakhstan hotels are available for booking online. Key advantage of Almaty and Astana consists in an opportunity online of booking and non-cash payment of most hotels. 
Low level of presence in the Kazakhstan tourist market of the international hotel brands is noted. All international hotel companies are in four business destinations: Astana, Almaty, Atyrau and Aktau.

The prices of accommodation in locations with the high level of hotel services are much higher, than in similar hotels in the leading tourist destinations of other countries. Room rate in the international branded hotels of category $5 *$ in the cities of Astana and Almaty 2-3 times higher, than in Europe. Service prices in other locations - boarding houses, tourist centers, shelters, camping, hostels for visitors and others - are much lower.

It is widely known that in the theory and practice of management existence of information means decrease in uncertainty and risk that leads to adoption of thought more over and reasonable administrative decisions. In the Republic of Kazakhstan in the sphere of tourism low degree of information security at all levels of relationship is observed.

Features of realization of a tourist product don't allow speaking about the full market without the corresponding information support. The Almaty tourist firms and bodies for management of tourism entering on the international market face in the activity problems of development of new information technologies which are a necessary condition of the international integration and the modern concept of tourist business as the information and saturated sphere. In this regard, now, the analysis of the existing information systems in tourism, studying of the main scopes of information technologies and development of recommendations is submitted to management of tourism on use of information systems especially relevant.

It should be noted that suppliers of tourist services use a number of the communication technologies capable to provide direct satellite covering of the international events, business by means of teleconferences from mobile intermedia (for example, an opportunity to make a call to any part of the world from a plane board). For obtaining information on the place of stay, his attractive features various videos of means are also necessary. As a result of use of information technologies safety and quality of tourist services increase, and there is no change of their obvious human contents at all.

Information technology for the provision and operation of airlines. Electronic systems play an important role in the organization, management and control of air operations, helping with the planning of routes and schedules, control and analysis of flight operations, personnel management of accounting and long-term planning. They include (for example) the system of transfer and direction of messages, the satellite system of collecting and information transfer for air transport, inertial navigation systems, the control system behind air transport, the system of sale of aviation tickets.

Ensuring high level of service in hotel in modern conditions can't also be reached without use of new technologies. The new technology provides automation of many hotel processes, electronic reservation, introduction of the technologies promoting improvement of quality of service at the same time at reduction of staff.

Network information technologies represent the relevant and perspective direction of information technology development. Their purpose - not only ensuring exchange of information between certain users of information systems, but also and creation of a possibility of cooperative use for them of the distributed information resources of society, obtaining reference, documentary and other information from different specialized information funds.

Thus, the system of the information technologies used in tourism consists of the computer system of reservation, the system of carrying out teleconferences, video systems, computers, information management systems, electronic information systems of airlines, electronic transfer of money, telephone networks, mobile intermedia, etc. At the same time it should be noted that this system of technologies is developed not by travel agents, hotels or airlines everyone, and all of them. Moreover, use by each segment of tourism of system of information technologies matters for all other parts. 
The analysis of the current state of foreign tourism in the field of information support of tourists has shown the following:

- in improving and entertaining tourism demand for operative and high-quality global communication and also for individual and collective receiving an informative and entertaining video information grows in the places of residence and on transport;

- in improving and sports tourism are of particular importance first-line information support in extreme situations and also information support of safety of tourists at means of systems of a weather forecast, observation and navigation; for example, information support of safety of elite sea tourism, sea races and individual travel is rather fully automated;

- in the system of excursion and informative tourism at equipment of museum and natural expositions multimedia means of collective (group) display of an explanatory and additional graphic and video information are used; individual and collective means of audio-and video support of excursions are also widespread;

- in youth travel means of communication, audio broadcastings and also computer virtual means of the game and training character take root now;

- in event tourism demand for means of audio-and video informing which allow to observe, for example, festive or sporting events from the different points of view is high;

- the great demand on photo and videos of the moments of their stay in historical and presentable places is characteristic of all forms of tourism.

In the field of information support of tourist intermediary structures it is possible to note the following tendencies:

- quickly club ways of informing the population, exclusively effective from the economic point of view, including about tourist products and services extend; at the same time the so-called virtual clubs equipped with multimedia means of collective display are created; it is important that these clubs promote formation of psychologically steady tourist groups;

- the automated information support of tour operator activity is transferred to modern computer and network technologies; the international automated booking systems function;

- telecommunication networks of the general access, for example the Internet, are actively used for placement of tourist advertizing and conducting "contractual" document flow; safety of application of such networks is ensured by formation of the international associations of users;

- regarding creation of a new tourist product processes of data collection and processing for carrying out management and marketing in various fields of tourism are automated;

- it isn't enough data on improving the level of automation of control tourist actions, identification and mitigation of consequences of emergency situations; however it is possible to assume that works in this direction are conducted, for example, at the initiative of insurance companies.

Proceeding from stated and experience EXPO-2017, the main long-term tendencies of tourism in Kazakhstan in general are:

- stable development of the international tourism with the subsequent increase in number of the international arrivals and the international tourism revenues that provides in general a positive market basis for development of the industry of tourism in Kazakhstan; 
- the growing tourist demand in the developing foreign markets, such as People's Republic of China, Republic of India, the Middle East and the Russian Federation. The geographical location of these countries gives an opportunity to develop tourist products for these markets and it is rather easy to realize them thanks to their proximity to Kazakhstan;

- rather great and stable demand in the developed foreign markets, such as Europe that gives to Kazakhstan an opportunity to realize the attractive and unique tourist products in these markets;

- the growing tourist offer from the developing destinations, such as the Azerbaijan Republic, People's Republic of China, Georgia, the Kyrgyz Republic, Mongolia, the Russian Federation, Turkmenistan and the Republic of Uzbekistan representing in the long term probability of the competition to the tourist offer of Kazakhstan;

- the high, growing and active competition, both among developed, and among the developing tourist destinations that demands from the Kazakhstan analogs of adequate positioning in this market, also as well as abilities to adapt to his continuously changing conditions.

At the present stage it is necessary to explore the attractiveness of the regions of the republic. Within the conducted research we have been the rating of readiness of regions of Kazakhstan for reception of guests. The systematic solution of problems of increase in appeal of regions of the republic to tourists, developments and deployments of additional programs of development of tourism in regions, their timely financing and modernization of the operating infrastructure will allow to increase in the future considerably appeal of all tourist regions of Kazakhstan.

Table 2. Rating of readiness of regions of Kazakhstan for reception of guests (estimate for 2017)

\begin{tabular}{|c|c|c|c|c|c|}
\hline Name of the region (city) & $\begin{array}{l}\text { The rank of the } \\
\text { regions in terms } \\
\text { of one-time } \\
\text { capacity (beds) }\end{array}$ & $\begin{array}{c}\text { One-time } \\
\text { capacity } \\
\text { (thousand beds) }\end{array}$ & $\begin{array}{c}\text { Scope of } \\
\text { services } \\
\text { (million euros) }\end{array}$ & $\begin{array}{l}\text { Number of } \\
\text { placements } \\
\text { (units) }\end{array}$ & $\begin{array}{c}\text { Occupied } \\
\text { placements } \\
(\%)\end{array}$ \\
\hline Total & & 119.3 & 39.38 & 2370 & 19.0 \\
\hline East Kazakhstan region & 1 & 22.3 & 1.69 & 378 & 19.2 \\
\hline Akmola region & 2 & 12.7 & 2.19 & 1628 & 13.4 \\
\hline Karagandy region & 3 & 12.3 & 1.69 & 3577 & 18.2 \\
\hline Almaty region & 4 & 11.2 & 1.48 & 96 & 17.3 \\
\hline South Kazakhstan region & 5 & 6.0 & 1.08 & 2883 & 16.4 \\
\hline Kostanay region & 6 & 5.8 & 0.43 & 1966 & 14.0 \\
\hline Pavlodar region & 7 & 5.7 & 0.61 & 2034 & 12.9 \\
\hline Mangystau region & 8 & 4.0 & 1.70 & 5154 & 15.3 \\
\hline Aktobe region & 9 & 3.9 & 0.72 & 2036 & 12.4 \\
\hline Atyrau region & 10 & 3.7 & 4.07 & 17682 & 28.0 \\
\hline Zhambyl region & 11 & 2.8 & 1.09 & 342 & 12.4 \\
\hline West Kazakhstan region & 12 & 2.8 & 1.69 & 4236 & 29.4 \\
\hline North Kazakhstan region & 13 & 2.3 & 0.30 & 657 & 13.4 \\
\hline Kyzylorda region & 14 & 1.6 & 0.35 & 560 & 15.2 \\
\hline $\begin{array}{l}\text { Astana - the city of republican significance - } \\
\text { the capital of Kazakhstan }\end{array}$ & & 9.5 & 10.29 & 35766 & 23.5 \\
\hline Almaty - the city of republican significance & & 12.7 & 9.98 & 62063 & 24.3 \\
\hline
\end{tabular}


The East Kazakhstan region - 120 thousand at a time can accept the greatest number of tourists (including residents). In the region 378 locations of guests function. In the area there is a resort area Katon-Karagay, Markakolsky and West Altai reserves.

The second place in rating at the Akmola region. The region in one stage can accept 22.3 thousand visitors. The area is attractive by resort areas in Shortandy, Zerende, Burabaye, the reserve Korgalzhyn.

On the third place - the Karaganda region. Single capacity of hotels of-12.7 thousand. The region is capable to attract Intourists with the resort area of Karkarala, the historical and cultural center of the first president and a recreation area of "Cabana Beach".

Afterwards Almaty region interesting to visitors by the reserve museum "Tamgaly", a Sharyn canyon and so on was located. The area is capable to accept at a time over the 11th thousand visitors. Here 315 hotels work.

The Southern Kazakhstan area where Intourists will be able to estimate advantages of rest in Sara-Agashe and to visit historical monuments in Turkestan closes the five of the best. Only 139 locations capable in total to receive slightly less than 6 thousand guests work in the southern region.

Besides the five of areas two largest cities of the country - Almaty and Astana in 291 hotels can accept 22 thousand visitors at a time. Two megalopolises bring more than a half of all volume of services, here too the highest fallibility of locations.

The quantity and degree of expressiveness of weaknesses of Kazakhstan are higher, than quantity and degree of expressiveness of his strengths that is usually characteristic of the country which, like Kazakhstan, is in development of the strong and competitive industry of tourism. However the quantity and degree of expressiveness of opportunities in Kazakhstan are higher, than quantity and degree of expressiveness of threats that means that the republic is able to use the current world processes and to create competitive advantage to development of the industry of tourism. Results of the carried-out SWOT analysis of tourist branch of Kazakhstan are presented in table 3. 
Table 3. SWOT-analysis of the tourism industry in Kazakhstan

\begin{tabular}{|c|c|}
\hline Strengths & Weaknesses \\
\hline $\begin{array}{l}\text { Natural, cultural, social and } \\
\text { economic characteristics of the } \\
\text { country: } \\
\text { - a variety of natural resources; } \\
\text { - a variety of monuments of tangible } \\
\text { and intangible cultural heritage; } \\
\text { - stable political and domestic } \\
\text { situation; } \\
\text { - the state of the labor market; } \\
\text { - the possibility of public funding; } \\
\text { - low cost of electricity and } \\
\text { construction. } \\
\text { Interested parties and partnerships: } \\
\text { - willingness of interested parties to } \\
\text { cooperate; } \\
\text { - readiness to create state-private } \\
\text { enterprises; } \\
\text { - availability of national tourist / } \\
\text { hotel associations. }\end{array}$ & $\begin{array}{l}\text { Low population density - a possible negative impact on the development of domestic tourism, } \\
\text { including through a low level of demand for tourism products within the country. } \\
\text { Insufficient level of involvement of historical and cultural monuments in tourist routes. } \\
\text { Lack of qualified personnel in the sphere of tourism. Tools of state support that require further } \\
\text { improvement, including stimulating the development of the industry through the introduction } \\
\text { of tax support measures, simplifying the entry formalities (visa, migration regime), improving } \\
\text { the land use regime, } \\
\text { Possible obstacles to the development of tourism business, including the presence of } \\
\text { administrative barriers, the availability of tools for government support, requiring further } \\
\text { improvement. } \\
\text { Insufficient development of infrastructure (transport, utility networks, checkpoints across } \\
\text { the State border of the Republic of Kazakhstan, the condition of roads, significant distance } \\
\text { between settlements, etc.), including significant physical and moral wear of a large number } \\
\text { of tourist industry facilities, the lack of tourist class hotels, inadequate development of } \\
\text { engineering, transport and social infrastructure in places of tourism, inaccessibility of tourist } \\
\text { facilities, low level of service in tourist places in, insufficient quantity and quality of service of } \\
\text { objects of a roadside infrastructure. } \\
\text { High prices for air tickets, the absence of national low-budget air carriers, a low number of } \\
\text { new inbound air routes from countries that provide a potential influx of tourists, as well as } \\
\text { domestic air routes in the direction of key tourist destinations identified in the cluster model of } \\
\text { tourism development in Kazakhstan. }\end{array}$ \\
\hline Opportunity & \\
\hline $\begin{array}{l}\text { Industry Trends: } \\
\text { - independent tourism; } \\
\text { - Ecological and natural tourism; } \\
\text { - cultural tourism; } \\
\text { - demand for special / adventure } \\
\text { tourist products; } \\
\text { - more frequent and shorter rest } \\
\text { periods; } \\
\text { - Active, wellness and sports rest; } \\
\text { - low-budget trips to the region; } \\
\text { - implementation of tour packages } \\
\text { via the Internet (e-commerce). }\end{array}$ & $\begin{array}{l}\text { Increasing the quality requirements. } \\
\text { Long travel and passing of control procedures at checkpoints on the State border of the } \\
\text { Republic of Kazakhstan for short-term rest. } \\
\text { The high cost of traveling over long distances. } \\
\text { Fragmentation of the travel market. } \\
\text { Availability of new distribution channels to competitors. } \\
\text { Similar tourist products of other regions (not only Kazakhstan is on the Great Silk Road, for } \\
\text { example). } \\
\text { Effective means of motivation and structure of entertainment; } \\
\text { Strong dependence on the volume of business trips. } \\
\text { Slow development of transport communication (air, land). } \\
\text { Instability of the currency and high inflation. }\end{array}$ \\
\hline
\end{tabular}

Source: composed by the authors

The geopolitical position and natural raw material resources allow counting on increase in number of the tourists coming to Kazakhstan concerning business and participation in the international actions. These are, first of all, the cities of Almaty, Astana, Atyrau. The geopolitical position and natural raw material resources allow counting on increase in number of the business tourists coming to Kazakhstan concerning business and participation in the international conventions. Infrastructure of the above-stated centers generally conforms to the international standards. The city of Almaty is strategic (air, automobile, railway) gate for the republic and the main migration happens through this city. Besides various forums of buildings and hotels, convenient for carrying out, the city has all necessary for rest and entertainments, besides in the territory of nearby to the city in a radius of $500 \mathrm{~km}$ remarkable recreational zones are located. The city of Astana becomes the same strategic zone. Ever-increasing interest in the city as to the young capital of our state having modern look and infrastructure will serve rapid development in the city of the international and internal tourism.

The analysis of tourist activity has shown that the tourists arriving from abroad prefer to stay at hotels, providing high-quality service and a full set of services. Further development of network of hotels of the international level in the large cities - business centers of the country will depend on business tourism. 
The most perspective regions of cultural and informative tourism are the city of Almaty and Almaty region, development of tourism in the Silk way (the international tourist train "Pearl of the Silk Way" along a route of Almaty - Turkestan - Tashkent - Samarkand - Bukhara - Urgench - Mary - Ashgabat - Almaty). Huge opportunities for development of internal cultural and informative tourism in the republic the "Silk Way" which is carried out under the auspices of UNWTO in cooperation with UNESCO opens participation of Kazakhstan in a tourist transcontinental route.

Ecological tourism can become one of the perspective directions of development of tourist branch in Kazakhstan according to us. The number of the tourists showing interest in reserved zones of Kazakhstan grows, new forms of organized tourism gain development: bicycle, horse, water. Need of development of ecological tourism in the Republic of Kazakhstan is caused not only economic factors - creation of new jobs, development of local communities in the remote regions, but also the social order - needs of the population for more complete, system approach to problems of health protection and use of free time. According to experts of World Tourism Organization, ecological tourism for the last ten years becomes the most popular and is one of instruments of sustainable development of any state.

\section{Conclusions}

Problems of the Kazakhstan economy in the conditions of openness and integration in world are relevant as demand search of effective state and economic mechanisms for deduction of relative economic stability and social development. Development of economy of Kazakhstan in market conditions revealed both competitive advantages of economic capacity of the country, and their shortcomings connected with various opportunities of adaptation to the market. It brought in the beginning of a stage of development of Kazakhstan as sovereign state to considerable recession and curtailment of productions in separate branches of the non-oil sector, aggravation of a disproportion of branches of real production sector towards development of branches of raw orientation. Inclusion of Kazakhstan in world economic system restrains narrow specialization of Kazakhstan in world and regional labor division, remoteness from the main world commodity markets.

Thus, the strategy of further economic development of Kazakhstan has to promote ensuring deduction of national economy at rather stable level on the basis of diversification of economy and creation of conditions by the state for production of competitive types of production and growth of non-oil export and also to creation of conditions for prevalence of private initiatives and equal competitive conditions for all subjects of the market.

In Kazakhstan tourism - the developing branch and influence of the tourist industry on national economy it is still insignificant. Backwardness of tourist infrastructure, low quality of service, the steady myth about Kazakhstan as about the country of the increased risk led to the fact that now less than $1 \%$ of a world tourist stream is the share of our country.

Indicator of tourist mobility of the population of Kazakhstan is one of the lowest in the world. An overwhelming part of travel agencies prefers to be engaged in the direction of the compatriots abroad, and only the few firms' work for involvement of tourists to Kazakhstan. And generally tourists visit Almaty and Astana.

The analysis of inbound tourism flows to Kazakhstan shows that the republic remains insufficiently attractive to foreign tourists. On export of tourist services Kazakhstan takes the 78th place in the world. On availability, the price and level of service, tourist services of Kazakhstan are not competitive in the world market and much more concede to foreign analogs including concerning information maintenance and support.

Unlike Kazakhstan information support of modern foreign tourism relies not only on the huge potential of the most modern radio electronics and the accurate organization of all production cycles, but also on the high level of information support of adjacent spheres of activity (bank, transport, hotel, museum, security, etc.) that considerably reduces functional loads of means of information support the tourism and at the same time essentially increases efficiency of their use. 
It is possible to allocate the following problems of formation and development of the mechanism of information support of development of internal and entrance tourism:

1. Decrease in information risk at decision-making in the sphere of management of tourism;

2. Improvement of coordination of actions between public authorities of various levels and also other participants of the market of internal and entrance tourism;

3. Improvement of the main characteristics of the used information: completeness, reliability, relevance and timeliness, availability, value;

4. Unification of processes of collecting, processing, use and dissemination of information;

5. Increase in tourist demand due to increase in knowledge of tourists of tourist opportunities of territories, etc.

Thus, the insufficient level of information support slows down development of entrance and internal tourism in Kazakhstan. Existence of full, reliable and relevant information promotes adoption of more effective administrative decisions and, therefore, increase in rates of development of tourism. The modern tourist industry basing on the unique and natural and cultural capacity of the Republic of Kazakhstan is a natural backbone factor of flexible integration of tourism into the system of world economic communications, one of the most dynamically developing and effective on return on the invested capital by branch, despite its capital intensity.

\section{References}

Boronenko, V.; Lavrinenko, O. 2015. Territorial development of Iceland: case study of social and economic interactions within global context. Social sciences for regional development in 2015: Proceedings of the X International scientific. Conf. (16-17 October 2015). Daugavpils University Latvia.

Delmon, J. 2015. Private Sector Investment in Infrastructure: Project Finance, PPP Projects and Risk. The World Bank and Kluwer Law International https://rus.wolterskluwer.com/store/product/private-sector-investment-in-infrastructure-project-finance-ppp-projects-and-ppp-frameworks-third-edition/

Dobrovolskienè, N., Tvaronavičienė, M., and Tamošiūnienė, R. 2017. Tackling projects on sustainability: a Lithuanian case study, Entrepreneurship and Sustainability Issues 4(4): 477-488. https://doi.org/10.9770/jesi.2017.4.4(6)

Jurigová, Z.; Tučková, Z.; Solenes, O. 2017. The impact of chosen economic indicators on tourism sustainability: case study of the Czech Republic and Norway, Journal of Security and Sustainability Issues 7(1): 113-121. https://doi.org/10.9770/jssi.2017.7.1(9)

Kvaratskhelia, M. 2017. World challenges and economics of Georgia, Journal of Security and Sustainability Issues 6(4): 619-625. https://doi.org/10.9770/jssi.2017.6.4(7)

Men̦šikovs, V.; Ignatjeva, S.; Stankevičs, A. 2014. Higher education's contribution into economic performance and innovativeness of Latvia: exploratory research. Retrieved from: http://www.ekof.bg.ac.rs/wp-content/uploads/2014/04/01.pdf

Official Internet-resource of Committee of Statistics of Ministry of the national economy of the Republic of Kazakhstan. Retrieved from: www.stat.gov.kz

Olefirenko, O.; Petrenko, E.; Shevyakova, A.; Zhartay, Z. 2016. Towards economic security through diversification: case of Kazakhstan, Entrepreneurship and Sustainability Issues 5(4): 509-518. http://dx.doi.org/10.9770/jssi.2016.5.4(6)

Sokolova, D. 2011. Information systems of booking in tourism.//The collection of scientific articles "Information technologies in economy, management and education”. Retrieved from: http://tourlib.net/statti_tourism/sokolova4.htm

Shevyakova, A. 2014. Features of the socio-economic stratification in the Republic of Kazakhstan. Social sciences for regional development in 2014: Proceedings of the IX International scientific. Conf. (17-18 October 2014). Daugavpils University Latvia.

Stjepanović, S.; Tomić, D.; Škare, M. 2017. A new approach to measuring green GDP: a cross-country analysis, Entrepreneurship and Sustainability Issues 4(4): 574-590. https://doi.org/10.9770/jesi.2017.4.4(13) 
Štiglic, D. 2017. Towards security through economic policy: a Baldwin's approach, Journal of Security and Sustainability Issues 7(1): 55-65. https://doi.org/10.9770/jssi.2017.7.1(6)

Tvaronavičienė, M; Gatautis, R. 2017. Peculiarities of income distribution in selected countries. Economics and Sociology, 10(4), 113123. http://dx.doi.org/10.14254/2071-789X.2017/10-4/9

Tvaronavičienė, M., Razminienè, K., Piccinetti, L. (2015). Cluster efficiency study through benchmarking, Entrepreneurship and Sustainability Issues 3(2): 120-128. http://dx.doi.org/10.9770/jesi.2015.3.2(0)

World Bank. 2015. Kazakhstan: Adjusting to Low Oil Prices, Challenging Times Ahead. Retrieved from: http://www.worldbank.org/en/ country/kazakhstan/publication/economic-update-fall-2015

Anna Shevyakova, PhD, Leading researcher, LLP "RATIONAL SOLUTION" Kazakhstan. Her research interests are related to macroeconomics, economic diversification, regional specialization, budget financing and state support for entrepreneurship development, innovation and development of "smart" territories.

ORCID ID: orcid.org/0000-0002-2644-6292

Irina Tyugina, Doctoral student of South Ural State University, Department of SME Development, The National Chamber of Entrepreneurs of Kazakhstan "Atameken". Research interests are related to economic diversification, regional specialization, regional economic development, state economic policy, non-governmental organizations, factors of economic growth.

ORCID ID: https://orcid.org/0000-0001-5160-3758

Malika Arystan, PhD, Associate Professor, Department of economic and management, Karaganda Economic University. Research interests are related to micro- and macroeconomics, international and regional economic development, state economic policy, factors of economic growth.

ORCID ID: https://orcid.org/0000-0003-4921-6577

Eleonora Munsh, Master of Engineering and Technology, Training and Development Department, EPAM Kazakhstan. Her research interests are related to Kazakhstan's economic sectors, pre-employment, non-governmental organizations, information technologies and support, computer networks, psychology and sociology.

ORCID ID: https://orcid.org/0000-0003-2395-6403 